\section{The Idea of a Research University in Russia}

\section{AnNa SMOlentseva}

Anna Smolentseva is a senior research fellow at the Institute for Educational Studies at Moscow State University. Address: 5/7 B. Nikitskaya Ul, Moscow, 125009, Russia. E-mail: asmolentseva@yahoo.com.

\begin{abstract}
A $\mathrm{s}$ in many countries of the world, the concept of the research university, its criteria, and functions have been discussed in Russia. Generally there are three major obstacles to developing such an institutional model in Russia. First, higher education historically was not the main source of knowledge production. Second, government funding of research, especially in higher education institutions, has broken down, and new sources of funding are limited. Third, for many reasons faculty are not ready to meet the challenge of knowledge production involved with the concept of research university.
\end{abstract}

\section{Two Models of Knowledge Production}

A partial separation between universities and research was instituted from the beginning of the university system. The basic research structure, the Russian Academy of Sciences, was established in Russia in the I8th century. In the 2 oth century Soviet policy strengthened the research role of the Academy of Sciences and government research institutes. Research institutes with doctoral programs concentrated on government-funded research. Meanwhile higher education was assigned the primary function of vocational training. However, certain "classical universities" and other leading higher education institutions, especially those working for the military complex, also conducted research. There institutions included research units such as institutes, centers, and laboratories; and they employed some research staff.

At the end of the Soviet era the collapse of government financing and planning led to a deterioration of the research institutes outside the universities in both material and human resources. Between 1990 and 2004 the total number of staff fell from about 2 million to $800,000,500,000$ of whom were research staff. The higher education system, which contributes a small number of research staff to the total number of R\&D personnel (about 5 percent), currently includes about 26,000 research staff. By comparison, public institutions employ about 300,000 faculty.

\section{RESEARCH EXPENDITURES}

The budgets of higher education institutions consist on average of funding for the provision of education (86 percent), with only 4.6 percent allocated for research and development. At major universities, particularly national ones, the level of research expenditures may have risen but remain low by international standards. For instance, according to its 2004 report, St. Petersburg State University spent about I2 percent of its budget on research, funded by ministries, Russian state foundations, international grants, and contracts with organizations. (There may be some further sources of research funds, but universities do not publish full and wholly transparent budgets.) Another example is Kemerovo State University, positioned in the 30 s in a ministry ranking, which spends just 5 percent on research.

The R\&D data of the Organization for Economic Co-operation and Development confirm the modest role of higher education regarding national research. In Russia only 5.5 percent of the gross domestic expenditure on R\&D is located in higher education, compared to I3.6 percent in the United States, I6.3 percent in Germany, 2I.4 percent in the United Kingdom, and 27.9 percent in the Netherlands.

\section{FACULTY RESEARCH}

One of the most important differences between the Russian system and many others is the extent of the focus on teaching. Government policy prescribes up to 9oo hours in teaching loads per year, with no less than 300 class hours for senior faculty and higher loads for junior staff.

\section{Government funding of research, especially in high-} er education institutions, has broken down, and new sources of funding are limited.

My 2006 Fulbright New Century Scholars survey included 703 faculty members at "classical," technological and pedagogical universities, and the most well-established institutions of higher learning in different Russian regions. Half the faculty (52 percent) reported they had never taken part in any research supported by nongovernmental research funds. These faculty may never have undertaken research other than for their dissertations and in projects carried out in departments with no research funding.

As a rule, financial support for research comes from Russian state foundations: over the last three years only 26 percent of all respondents had participated in foundation-financed work. Some funding was provided by Russian organizationsincluding industry, business, and other sources (I4 percent) and from universities or departments (I3 percent). Governments at various levels funded ro percent of faculty. Foreign funding comprises a notable component: 9 percent of faculty received grants from international foundations and 3 percent took part in work funded by foreign organizations.

The publication records of faculty reflect low levels of research activity. In the previous three years 58 percent of faculty had not published any articles in Russian refereed journals, and another 29 percent had published only one or two 
articles. Furthermore, 8 percent published at least one paper in a foreign refereed journal. Overall, faculty who were relatively active in research constituted only about 5 percent of all academic staff in the study-that is, when the measurement of "research active" consists of publications in Russian and international refereed journals as well as grant activity of faculty.

\section{Prospects for the Research University}

The challenges of globalization suggest that research activity in Russian universities should be intensified. A survey of faculty research in Russia shows that the higher education system is far from achieving an appropriate level of research activity. Among the factors working against this progress are the Soviet tradition of allocating research mostly to research institutes, the traditionally high teaching loads of junior and middle academic personnel, inadequate government funding of universities, and limited opportunities for faculty to raise research funding directly. Faculty members need to spread themselves among multiple jobs because one salary is not enough to live on. Besides, a model of appropriate knowledge production requires a certain financial autonomy of research organizations, whatever their kind. In Russia such autonomy has been shrinking, especially in higher education institutions and also requires appropriate legislation on intellectual property. These conditions simply are not in place.

Under present circumstances Russia cannot build knowledge production as a national asset and develop a robust research university sector. The external incentives for research are weak, in a natural resources-based economy with a state sector whose priorities now seem to be elsewhere. The internal mechanisms governing faculty research are also weak (e.g., evaluation and peer-review practices). Cultures of strong research performance and productivity are on average absent.

In the post-Soviet period, government has initiated a set of programs designed to encourage the integration of higher education and research. However, genuine integration faces legal, organizational, social, and psychological barriers.

\section{No World-Class University Left Behind}

\section{ROBERT BIRNBAUM}

Robert Birnbaum is professor emeritus of higher education at the University of Maryland, College Park. E-mail: rbirnbau@mail.umd.edu.

I don't wish to appear alarmist, but to judge from the growing literature we appear to be facing a world-class university ranking crisis. The problem is not the lack of such lists but rather that they are too numerous and too different.

Without uniform rankings, many institutions across the globe claim that they plan to become world-class universities by a certain date or that they have already achieved this status. World-class status has been projected or claimed for institutions in Vietnam, Turkey, Chile, Kashmir, and Malaysia, among other countries. Thailand has been particularly blessed by three institutions with such aspirations. The University of Timbuktu (which apparently was a world-class university in the I2th century) has announced its intention of regaining that status; and the president of the Kazakhstan Institute of Management, Economics and Strategic Research has claimed world-class status, even as the source of the institution's accreditation is being questioned.

As for the United States, a list of acknowledged or self-proclaimed world-class universities include not only the usual suspects of Association of American University members and

World-class status has been projected or claimed for institutions in Vietnam, Turkey, Chile, Kashmir, and Malaysia, among other countries.

wannabes but also a number of institutions that some observers would identify as having merely regional or local recognition. The United States can, however, probably boast having the only institution actually named World Class University. I was hoping that studying this institution (in Tennessee) might clarify the problem until I read their selfidentification on the Internet as "the only barber college teaching the New Millennium Fading Technique."

Perhaps globalization is to blame. For some people the concept suggests the desirability of constructing a single measure of world class that can be uniformly applied to institutions across all nations. In an effort to encourage scholars to think outside the hegemonical box, I propose to consider five alternative ways to go about identifying world-class institutions. Each alternative has its foundations in a sound conceptual orientation.

Bentham System - this scheme, based on the Igth-century English philosopher Jeremy Bentham's principle of utilitarianism, proposes that the best universities are those that bring about the greatest happiness to the greatest number of people. Certainly the intellectual pleasures created by the development of a new theory should be included in developing the Bentham ratings. However, should not the pleasures obtained by students in their university experiences, whether in their dorm rooms or classrooms, be given equal weight? After all, there are many sources of happiness and little justification for selecting one source as superior to another. As the Igth-century French politician and gourmet Jean Anthelme Brillat-Savarin said in his classic book, The Physiology of Taste, "the discovery of a new dish confers more happiness on humanity than the 